Ekong suggested solving this problem by compelling all industrial enterprises in Nigeria to contribute to a fund for local industrial R \& D. They would be able to claim rebates depending on how much they spent on local $R \& D$. He also suggested that tax incentives be given to industrics based on local knowledge and raw materials.

Ekong believes that without significant input from the universities there will be no self-sustained growth in industrialisation in the foreseeable future. However, because governments regard rescarch facilities as luxuries developing countries can ill afford, "most chemical laboratories in our universities are ill-equipped and lack basic facilities for even the most elementary research", says Ekong. "Lack of scientific leadership is the principal reason for the low scientific

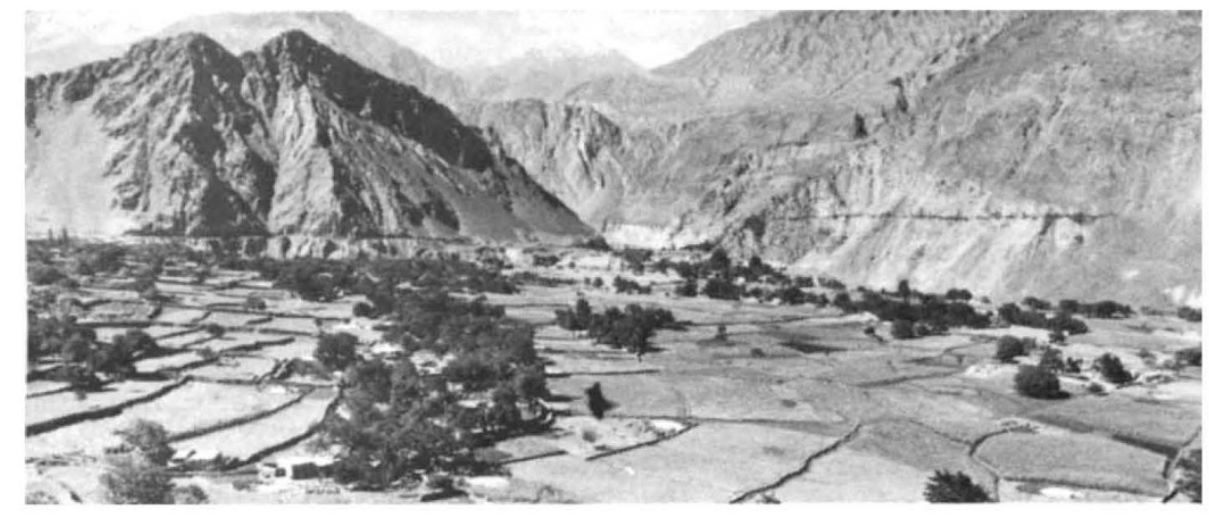

\section{Pakistan reorganises agricultural research after harvest disaster}

AFTer a disastrous wheat harvest in Pakistan last year (the shortfall in expected production was 1 million tons), the Pakistani government has had to import $\mathbf{2 . 2}$ million tons of wheat at a cost of 4,000 million Rupees (\$400 million). The had crop came as a particularly hard blow because the country had hoped to achieve selfsufficiency in food last year and wheat is its staple food.

The poor crop can be attributed to the fact that $75 "$ " of the wheat was afflicted by rust. The main reason for such widespread infection seems to be due to the fact that the popular commercial wheat varieties used had not been bred for rust resistance.

The Pakistani government lays the blame with its agricultural policy and the way in which the country goes about agricultural research. There are agricultural research institutes in Pakistan but most of them arc isolated in the provinces and suffer from a lack of central coordination. Most of their research on brecding has centred on improving yields. Brceding resistance to adverse conditions such as disease or weather has been largely overlooked. And many very important aspects of agricultural research such as climatology. plant biology, agronomy and pathology are barely covered at all.

1)r Amir Mohammad, chairman of the Agricultural Research Council in Karachi has plans to improve Pakistan's agricultural research. The ARC has already drawn up the following measures for quick implementation:
- The creation of a National Agricuitural Research Centre. This is already being built in Islambad on 1,300 acres of land. It is planned as a centre of excellence for agricultural research and is being funded by Pakistan and to the tune of $\$ 19$ million by foreign grants and loans.

The centre will consist of institutes on agricultural climatology, plant biology, agricultural data and planning, agricultural engineering and machinery, forestry, fisheries, water-shed management, arid-zone research, rural sociology, and a national plan introduction centre. Building should start in mid1979 and the centre should be functioning in about three years time.

- The creation of a National Commodity Institute under the ARC. This will conduct research into individual crops and livestock. It will consist of separate sections for each major crop, such as wheat, rice, sugarcane, and cotton and a livestock section. Existing provincial research institutes will remain but will be under the NC.I and the NARC.

- Manning of the institutes. 150 firstrate scientists will be needed. Pakistan is short of such manpower, so it plans to put new graduates into a six-month training course and then to send most of them for further training abroad.

- The division of the country into eight agro-ecological zones each carrying a different climate and ecology. An advisory committee of scientists and local farmers for each particular zone, will meet periodically to assess local output and is an area where international collaboration could be fruitful. Dr C. C. Mjojo from Chancellor College, Malawi, pointed out that there was little difficulty in finding money for applied research but support was needed for the pure natural sciences.

Lynette Hamblin

Lynette Hamblin is editor of Education in Chemistry

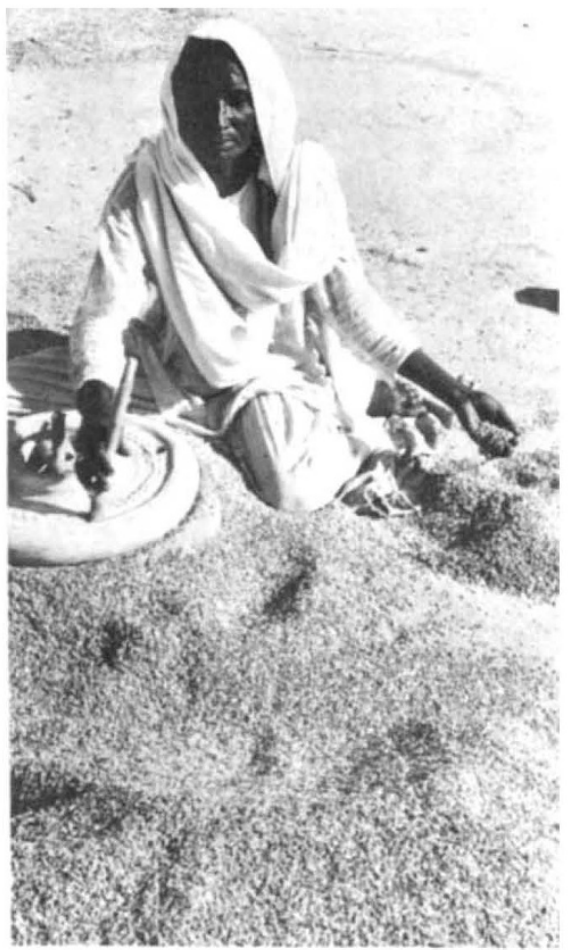

Grain production in Pakistan. Top left: terraced farming. Above: grinding wheat.

conditions and recommend measures for ensuring optimum output.

- Strengthening of the small cereal Diseases Research Institute operating under the ARC so that it can incorporate studies of new cereal pathogens and screen new cereal strains for resistance to various rusts.

- The development of a coordinated research programme. ARC plans to have a strong research group on the socio-economic aspects of agriculture, which will also deal with large and small-scale planning of the country's agricultural resources.

At a Wheat Research and Production Seminar held in Inslambad last August, Dr Norman Borlaug, Director of CIMMYT, Mexico, expressed the view that Pakistan could increase its wheat production from 8-9 million tons to 15 million tons if farm production was made more efficient. At present, in spite of the 'Green Revolution', the wheat yield in Pakistan is quite low. As against Mexico's 4,175 $\mathrm{kg} /$ Hectare, Egypt's 3,343, and the US's 2,022, wheat production in Pakistan is only $1,411 \mathrm{~kg} /$ Hectare.

Azim Kidwai 